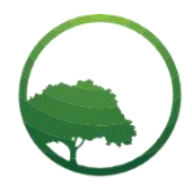

Research in Business \& Social Science

IJRBS VOL 10 NO 4 ISSN: 2147-4478

\title{
Effects of workplace loneliness and perceived organizational support towards intention to leave mediated by organizational commitment
}

\author{
(iD) Desi Wahyuni (a) (iD) Muafi ${ }^{(b) *}$ \\ (a) Magister of Management, Universitas Islam Indonesia, Indonesia \\ (b) Professor, Management Department, Universitas Islam Indonesia, Indonesia
}

\author{
ARTICLE INFO \\ Article history: \\ Received 16 April 2021 \\ Received in rev. form 25 May 2021 \\ Accepted 27 May 2021 \\ Keywords: \\ Workplace Loneliness, Perceived \\ Organizational Support (POS), \\ Organizational Commitment, \\ Intention to Leave, Securities \\ Company \\ JEL Classification: \\ O15
}

\begin{abstract}
A B S T R A C T
The aim of this research is to examine and analyze effects of workplace loneliness and perceived organizational support towards Intention to Leave mediated by organizational commitment. This research was conducted on the employees of securities company that are part of Indonesian Stock Exchange (BEI), specifically located in D.I. Yogyakarta and Central Java, with a total sample of 101 respondents. The data analysis used for this research is quantitative method of Structural Equation Modeling (SEM) with result that shows; (1) There is a negative and significant correlation between Workplace Loneliness towards Organizational Commitment, (2) there is a positive and significant correlation between Workplace Loneliness towards Intention to Leave, (3) there is a positive and significant correlation between Perceived Organizational Support towards Organizational Commitment, (4) Perceived Organizational Support has a negative and significant correlation towards Intention to Leave, (5) there is a negative and significant correlation between Organizational commitment towards Intention to Leave, (6) there is a positive and significant correlation between Workplace Loneliness towards Intention to Leave through the variable of Organizational commitment, and (7) there is a negative and significant correlation between Perceived Organizational Support towards Intention to Leave through the variable of Organizational commitment among the employees of securities company that are parts of Indonesian Stock Exchange (BEI), specifically located in D.I. Yogyakarta and Central Java.
\end{abstract}

(C) 2021 by the authors. Licensee SSBFNET, Istanbul, Turkey. This article is an open access article distributed under the terms and conditions of the Creative Commons Attribution (CC BY) license (http://creativecommons.org/licenses/by/4.0/).

\section{Introduction}

One of the most rapid technology advancements in this digital era is the advancement of the internet, which contributes to the increase of loneliness as direct interaction among individuals gradually decreases. In this era, technology serves as a tool that makes humans' daily needs easier. There are both positive impacts and negative impacts of nowadays technology advancements. One of the negative impacts is the lack of social interaction, which can evoke a feeling of loneliness. Loneliness is defined as a concept that defies the nature of humankind, as humans are always in need of social communication and social interaction (Cacioppo \& Patrick, 2008)

Loneliness at work is marked with unwanted thoughts that are caused by the absence of qualitative interpersonal relation and the inability of socializing (Wright et al., 2006) Workplace loneliness is not a new phenomenon, only that it has become more common nowadays. However, workplace loneliness has not been a subject of research, both theoretically and empirically.

In an organization, good social interaction and interpersonal support are not enough; there is an organizational support that is deemed as a reflection of employees' perception towards how far an organization appreciates their contribution and cares for their welfare. Organizational support can increase the optimism among employees that an organization will provide more appreciation for the sake of pursuing the goal of an organization (Eisenberger et al., 1986) Organizational support is also said to have positive correlation with many welfare factors, as how organizational commitment does. POS is considered to be the main predictor of Intention to Leave. As POS increases, the intention for turnover decreases as POS evokes the sense of responsibility towards an organization (Tuzun \&

* Corresponding author. ORCID ID: 0000-0002-5078-4670

(C) 2021 by the authors. Hosting by SSBFNET. Peer review under responsibility of Center for Strategic Studies in Business and Finance.

https://doi.org/10.20525/ijrbs.v10i4.1212 
Kalemci, 2012). On the other hand, employees with low level of POS tend to resign from an organization (Jawahar \& Hemmasi, 2006)

This research was conducted on employees of securities companies that are parts of Indonesia Stock Exchange (BEI), specifically located in DIY and Central Java. Securities company serves an important role in facilitating people to invest in the stock market as convenient as possible. With the help of securities company, people can conduct capital transaction in exchange for investment products they desire. However, the rapid development of technology actually causes these employees to have excessive workload that it becomes a major issue among them. This issue can trigger many other following conflicts that further meddles in their family and social interaction among employees, hence the decrease in their work performance.

For employees of a company, organizational support is seen as a form of support that is granted by the company for its employees, to both increase their work performance as well as their organizational commitment. Based on the existing experience and phenomenon, employees of securities company are often dissatisfied if the company offers no promising career path and if the company lacks in respect towards the employees, further causing the employees to consider resigning and looking for other companies that can elevate their careers.

According to some studies (Ayazlar \& Guzel, 2014) (Ozcelik \& Barsade, 2018), it is shown that there is a negative and significant correlation between loneliness and organizational commitment. This is where employees that experience loneliness in their work group will gradually eliminate their affective commitment towards an organization, be it because of psychological reason or interpersonal reason. In line with this, it is revealed that workplace loneliness has a negative correlation with organizational commitment, yet has a positive correlation with Intention to Leave (Wright, 2005). Loneliness is said to cause stress, weakening of organizational commitment, and problems related to social interaction, which induce the desire to resign from an organization (Kaymaz et al., 2014). Moreover, the studies conducted by Madden et al., (2015) and Ghozali et al., (2018) similarly show that POS has a negative correlation to Intention to Leave. Other studies by James \& Azungah (2019) and Guchait et al., (2015) show that there is a significant and negative impact between organizational support and Intention to Leave, mediated by organizational commitment among employees.

It is discovered that there is a difference in result regarding the influence of workplace loneliness with Intention to Leave that is mediated by organizational commitment. In a study conducted by Ertosun \& Erdil (2012), the result shows that affective commitment does not have mediation effect on the relation between emotional deprivation and Intention to Leave. On the other hand, affective commitment has mediation effect on the relation between social friendship and Intention to Leave. Workplace loneliness also has a negative impact on employees' attitude, which contributes to the low level of organizational commitment and Intention to Leave.

Wright et al. (2006) discussed the importance of this matter, arguing that the concept of workplace loneliness may not only have different causes, but also different consequences. There is a gap in some previous research and that is the difference in result of research. Therefore, this research is aimed to fill the gap in research literature and to contribute theoretically to this discourse by developing and examining the model of research on the impact of workplace loneliness and perceived organizational support towards Intention to Leave mediated by organizational commitment, which is surveyed among employees of securities company that are parts of Indonesian Stock Exchange (BEI), specifically located in D.I. Yogyakarta and Central Java.

\section{Literature Review}

\section{Workplace Loneliness and Organizational Commitment}

According to Barsade and Ozcelik (2011), in a specific term, loneliness is a feeling that involves isolation and alienation from other people in a social environment. Having this feeling of alienation and lack of security leads to a deficit of attention and relational withdrawal from the workplace, leading to decreased performance. Lack of social interaction for a human can lead to feelings of loneliness. Loneliness is a concept that is contrary to nature because humans always need social communication and social interaction (Cacioppo \& Patrick, 2008). The loneliness of employees in an organization can negatively affect their commitment to the organization, where the lonelier a person is, the lower the commitment will be, even at a lower level. The results of Chan and Qiu's (2011) study indicate that there is a significant negative correlation between loneliness and organizational commitment. Meanwhile, study conducted by Ozcelik and Barsade (2018) revealed that workplace loneliness has a negative effect on organizational commitment. In a study conducted by Tabancalı and Korumaz (2017), it showed that supervisors' workplace loneliness strongly predicts their commitment to the organization. On the other hand, study conducted by Promsri (2018) shows that continuous commitment and normative commitment have a significant positive effect on workplace loneliness, whereas affective commitment has a significant negative effect on workplace loneliness. Based on the relationship between the two variables, the first hypothesis is:

H1: Workplace Loneliness has a negative effect on Organizational Commitment.

\section{Workplace Loneliness and Intention to Leave}

Ertosun \& Erdil (2012) stated that loneliness can come from low social support. If an employee has low social relations at work, then he tends to have a greater desire to do the intention to quit. Loneliness has been associated with various individual differences which include depression, hostility, pessimism, feelings of isolation from social interactions, shame, and low positive engagement. Where 
if an employee feels lonely at work, either emotionally or socially, then they tend to psychologically withdraw from the organization or workplace environment. Workplace loneliness has a negative effect on employee attitudes, which can lead to low organizational commitment and a desire to leave the organization. Lam \& Lau (2012) explain that employees who have social relationships and trust that are less likely to be prioritized and appear for the organization. This makes them feel that their goals are not in line with the goals of the organization, thus encouraging them to seek alternative assistance from other organizations. This is in line with study conducted by Aytac and Basol (2018). The results of this study indicate that there is a positive and significant influence between loneliness and Intention to Leave. Kaymaz et al., (2014) show that the results of this study are that there is a positive and significant influence between loneliness and Intention to Leave. In addition, study conducted by Ghadi (2017) states that workplace loneliness has a positive and significant impact on employee Intention to Leave. Study by Gozukara et al., (2017) shows that Intention to Leave affects loneliness and the effect of Intention to Leave on loneliness is completely mediated by job alienation. Based on the relationship between the two variables, the second hypothesis is:

H2: Workplace Loneliness has a positive effect on Intention to Leave.

\section{Perceived Organizational Support and Organizational Commitment}

Perceived organizational support is also an important factor in supporting organizational and employee functions. Support can be in the form of praise which is given to employees indiscriminately. When employees feel that their organization values their contributions and cares about their well-being, they will express a higher degree of affective, normative, and continual organizational commitment. Conducted by Wong and Wong (2017) the results of this study indicate that POS has a positive effect on organizational commitment. Battistelli et al., (2015) also found that POS has a positive effect on self-competence through affective commitment. Conversely, ongoing commitment and normative commitment do not mediate this relationship. Wong and Wong, (2017) also show that POS has a positive effect on organizational commitment. Meanwhile, study conducted by Kim et al., (2016) shows that POS has a positive effect on Affective Commitment. Perceived organizational support theory argues that POS fulfills socio-emotional needs such as appreciation, affiliation, and emotional support, leading to greater organizational identification, which in turn will increase AC. In addition, Brown and Roloff (2015) show that perceived organizational support has a positive effect on organizational commitment. Likewise, study conducted by Nazir and Islam (2017) found a positive influence of perceived organizational support on employee organizational commitment. Islam et al., (2015) also show that the study conducted had a positive and significant relationship between perceived organizational support and affective commitment felt by employees in the banking sector. POS is believed to increase employee affective commitment. Based on the relationship between the two variables, the third hypothesis is:

\section{H3: Perceived Organizational Support positively affects Organizational Commitment}

\section{Perceived Organizational Support and Intention to Leave.}

Employees with a high perceived organizational support have a higher positive attitude towards their job so that their intention to leave will decrease. The results of this study indicate that organizational support can reduce employees' intention to leave the organization. In addition, employees who feel that the organization has appreciated their contributions and care about their welfare will reciprocate those feelings to the organization by staying with the organization. Barzoki and Rezai (2017) found that POS has a negative and significant effect on Intention to Leave. The relationship between POS and Intention to Leave provides opportunities for managers to retain valuable employees for the company. Meanwhile, the results of the study by James and Azungah (2019) show that the direct relationship between Organizational Support and the intention to leave without a mediator is negative and significant. Guchait et al., (2015) found that POS has a negative and significant effect on the intention to leave, where the higher the perceived high organizational support, the lower the desire to leave the organization. Study by Madden et al., (2015) shows the same results in which POS has a negative effect on Intention to Leave. Meanwhile, Ghozali et al., (2018) show that POS has a negative and significant effect on the desire to leave the organization. This shows that with the increase in POS, employees will have lower intention to leave so that the intention will increase along with the increase in POS. Barzoki and Rezai (2017) found that POS has a negative and significant effect on Intention to Leave. Likewise, study conducted by Akgunduz and Sanli (2017) shows that POS has a negative effect on Intention to Leave. Based on the relationship between the two variables, the fourth hypothesis is:

H4: Perceived Organizational Support has a negative effect on Intention to Leave.

\section{Organizational Commitment and Intention to Leave}

The desire to leave is the tendency or degree to which an employee is likely to leave the organization. In which employees who have high organizational commitment will have low intention to leave. With the increase of job satisfaction and organizational commitment, it is expected that the employee's intention or goal to leave the organization will decrease. Mowday (1987) concluded that individuals who meet the organizational commitment will have high levels of job satisfaction and lower desire to leave. Study conducted by Rawashdeh and Tamimi (2019) shows that organizational commitment has a negative effect on Intention to Leave. In addition, Jehanzeb et al., (2013) also stated that organizational commitment has a negative effect on Intention to Leaves. Where the low level of training programs in the organization can lead to poor employee performance and higher employee turnover rates. On the other hand, Omar (2012) found that only one dimension of organizational commitment has a significant negative relationship with the desire to leave the organization, namely affective commitment. Meanwhile, results from a study by Islam et al., (2015) show that there is a negative and significant relationship between Affective Commitment in relation to Intention to Leave felt by employees 
in the banking sector. However, Ertosun and Erdil (2012) concluded that affective commitment has no mediating effect on the relationship between emotional deprivation and the desire to leave. Whereas affective commitment has a mediating effect on the relationship between social friendship and the desire to leave. A negative relationship was also found between organizational commitment and intentions to leave from study conducted by (Ghozali et al., 2018). The results show that employees with better organizational commitment are less likely to have the desire to leave their current jobs. Based on the relationship between the two variables, the following is the hypothesis that is proposed:

H5: Organizational Commitment has a negative effect on Intention to Leave.

\section{Workplace Loneliness, Intention to Leave, and Organizational Commitment}

In line with study conducted by Wright (2005), workplace loneliness is negatively correlated with organizational commitment and positively related to Intention to Leave. If the organization is unable to meet its employee's needs, such as the need for intimacy and social relations, the employee's organizational commitment will decrease, leading to an increased likelihood of leaving the current organization to find more satisfying interpersonal relationships. From the results of study conducted by Kaymaz et al., (2014), it is suggested that loneliness can cause stress, weak organizational commitment, and problems in social relationships, which in turn can trigger a desire to leave the organization. Results from the study conducted by Ertosun and Erdil (2012) show that Affective Commitment has a mediating effect on Loneliness and Intention to leave. It is known that there are 2 dimensions in this study, namely emotional deprivation and social loss which are positively related to Intention to Leave. Both can positively predict Intention to Leaves; Emotional deprivation and social deprivation are negatively associated with emotional commitment and social deprivation. Based on the relationship between the two variables, the following is the hypothesis that is proposed:

H6: Workplace Loneliness has a positive effect on Intention to Leave and Organizational Commitment.

\section{Perceived Organizational Support, Intention to Leave, and Organizational Commitment}

Maertz et al., (2007) in their study show that normative and affective commitment can mediate the relationship between POS and Intention to Leave. A person who has great organizational support and has a strong drive to increase his organizational commitment which lead to a positive mood at work can lead to positive emotional associations with the organization itself, thereby increasing affective commitment and reducing turnover rates. The results of Wong and Wong's (2017) study show that affective commitment mediates the relationship between POS and employee Intention to Leave. Affective commitment has a negative and significant effect on Intention to Leave and POS has a significant positive effect on affective commitment. The results from a study by Albalawi et al., (2019) show that organizational commitment is a mediator between POS and Intention to Leave and their relationship becomes weak when employee job satisfaction is high. Job satisfaction has been shown to increase organizational commitment and reduce the desire to leave. So it can be concluded that POS can increase organizational commitment and further reduces the intention to join and to leave the organization. Meanwhile, Kalidass and Bahron (2015) show that there is a significant relationship between perceptions of organizational support and organizational commitment to employee Intention to Leaves. In addition, Tao (2019) also found that POS affects Intention to Leave through the affective commitment variable. Based on the relationship between the two variables, the following is the hypothesis that is proposed:

H7: Perceived Organizational Support has a negative effect on Intention to Leave Mediated by Organizational Commitment.

\section{Research and Methodology}

This research is a quantitative descriptive study and was conducted in securities companies as members of the Indonesia Stock Exchange in Central Java and the D.I. Yogyakarta. The population in this study are all employees who work in securities companies as members of the Indonesia Stock Exchange, representative offices for the area of D.I. Yogyakarta and Central Java, totaling 200 employees. The technique used in collecting data to support this research is non-probability sampling. While the method used in sampling is purposive sampling. This method is used because researchers were focusing on target respondents who have been adjusted to certain criteria. As the result, there were 133 respondents in this study and only 101 respondents who were returned and could be used for further analysis.

\section{Workplace Loneliness}

Workplace loneliness is a work-related feeling where someone feels isolated and unwanted by others which results in decreased social interaction between employees at work. The indicators used to measure Workplace Loneliness include:

\section{Emotional Deprivation}

- Often feels neglected by coworkers when under work pressure

- Often feels alienated by coworkers

- Experiencing a feeling of emptiness while at work

- Feel satisfied with the relationships I have at work 


\section{Social Companionship}

- Have friendly social relationships at my workplace

- Have a coworker who can be trusted to help with problems at work when in need

- $\quad$ Feeling part of a group of friends at work

\section{Perceived Organizational Support}

Perceived Organizational Support is the support shown by an organization for positive things done by employees by appreciating the employee's contribution provided by employees and paying attention to their overall welfare. The indicators used to measure Perceived Organizational Support include:

\section{Employee performance}

- The organization appreciates my contribution to its well-being

- The organization takes pride in my accomplishments at work

Appreciation for the extra efforts of employees

- The organization failed to appreciate the extra effort I put into it

- The organization will ignore any complaints from me.

Employee satisfaction at work

- The organization cares about my satisfaction at work

Employee wellbeing

- The organization ignores my interests when making decisions that can affect me

- The organization doesn't really care about me

Improved performance

- Even if I do my best on the job, the organization doesn't pay attention to it

\section{Organizational commitment}

Organizational commitment is the attitude or form of a person's behavior towards the organization in the form of loyalty and support in achieving the vision, mission, and goals of the organization. The indicators used to measure Organizational Commitment include:

\section{Affective Commitment}

- Would love to spend the rest of my career in this organization

- Feels that if there is a problem in the organization, then that problem is also my problem

- Feel that I can easily become attached to other organizations

- Doesn't feel like "part of the family" in the organization

- This organization has personal meaning for employees

\section{Continuance Commitment}

- Not afraid of anything that might happen if I quit this job

- It will be very difficult to leave this organization

- If I leave the organization there will be many problems

- For now, staying in the organization is a necessity

Normative Commitment

- Does not believe that one should always be loyal to the organization

- It is unethical to move from one organization to another

- One of the main reasons to keep working for this organization is because I believe that loyalty is important and therefore I feel I have a moral obligation to stay

- It would be better if the employee stayed with one organization for most of their career

\section{Intention to Leave the Organization}

The intention to leave the organization is the desire of employees to quit their jobs in the near future and leave the organization voluntarily because of dissatisfaction with their current jobs and organizations. The indicators used to measure Intention to Leave the Organization include: 


\section{Intention to Quit}

- Often think about leaving work

- Doesn't feel obligated to stay with the current organization

\section{Intention to Search for Alternative}

- I will leave the organization if I can find a similar job at another organization

\section{Thinking of Quitting}

- $\quad$ Might be looking for another job soon

The indicators used for this research were adopted based on previous studies. This study uses data collection techniques with a questionnaire method. Distribution of questionnaires using a Google form. The questionnaire consists of several statements given to respondents in the hope that they can be filled in according to the given instructions. In this study, a Likert scale was used with an interval scale of 7 scales, namely " $1=$ strongly disagree", " 2 = disagree", " 3 = somewhat disagree", "4 = neutral", " $5=$ somewhat agree", "6 = Agree "," 7 = Strongly Agree ".

In this study, researchers tested models and hypotheses using the PLS technique. The analysis was using SEM-PLS (Partial Least Square) which consists of two parts, namely the evaluation of the outer model and the evaluation of the inner model. Evaluation of the outer model aims to determine the validity and reliability of measurement instruments in the research model. Outer model analysis can be seen from the values of convergent validity, construct validity, discriminant validity, and composite reliability. Inner model testing or structural models is carried out to predict causal relationships between variables or hypothesis testing. Inner model analysis can be seen from the coefficient of determination (R2), Q-square predictive relevance and hypothesis testing (influence between constructs).

\section{Result and Discussion}

\section{Analysis of the respondents' characteristics.}

In this study, female respondents compared to male respondents showed that the composition of the number of male and female employees was almost the same, namely $50.5 \%$ while male employees were $49.5 \%$. This shows that the composition of the number of male and female employees is almost the same, meaning that the roles and contributions of male and female employees are the same in carrying out tasks in the Securities Companies. The characteristics of respondents based on age indicate that the majority are still young, namely, between 21-26 years of $42.6 \%$, young employees tend to have big dreams and ideals, so that the possibility of moving to work is still high. In addition, the majority are S1 graduates which amount to 74, 3\%. The majority of the employees' monthly income is more than 6 million which amounts to 33.7\%. This shows that the salary or income of employees per month is quite large, so it is hoped that there will be no Intention to Leave due to salary or compensation factors. The majority of employees work for 1 - 3 years, namely $45.5 \%$, meaning that the majority of employees have not worked in securities companies for a long time.

Table 1: Respondents' Descriptive

\begin{tabular}{llll}
\hline Demography & Description & Number & Percentage \\
\hline Gender & Male & 50 & $49.5 \%$ \\
\hline Age & Female & 51 & $50.5 \%$ \\
\hline & $21-26$ Years & $42.6 \%$ \\
\hline & $27-32$ Years & 21 & $20.8 \%$ \\
\hline Education & $33-42$ Years & 29 & $28.7 \%$ \\
\hline & $>$ 45 Years & 8 & $7.9 \%$ \\
\hline & High School & $6.9 \%$ \\
\hline Salary & D3/D4 : & $5.0 \%$ \\
\hline & S1 : & 5 & $74.3 \%$ \\
\hline & S2 & 75 & $14.9 \%$ \\
\hline Length of Employment & 2 Million - 3,5 Million & $27.7 \%$ \\
\hline & 3.6 Million - 4,5 Million & $21.8 \%$ \\
\hline & 4.6 Million - 5,5 Million & 15 & $3.8 \%$ \\
\hline & $>6$ Million & 28 & $33.7 \%$ \\
\hline Total & $1-3$ Years & 22 & $45.5 \%$ \\
\hline
\end{tabular}




\section{Outer Model Testing Results}

Testing the measurement model will be carried out to show the results of the validity and reliability tests. Using convergent validity and discriminant validity. Convergent validity is intended to test each construct of the uni-dimensionality model by looking at the convergent validity (Outer Loading) of each construct indicator. An indicator is considered to have good reliability if the value is greater than 0.70 . While the loading factor of 0.50 to 0.60 can still be maintained for models that are still in the development stage. Based on these criteria, indicators whose loading factor values are less than 0.50 are excluded from the analysis.

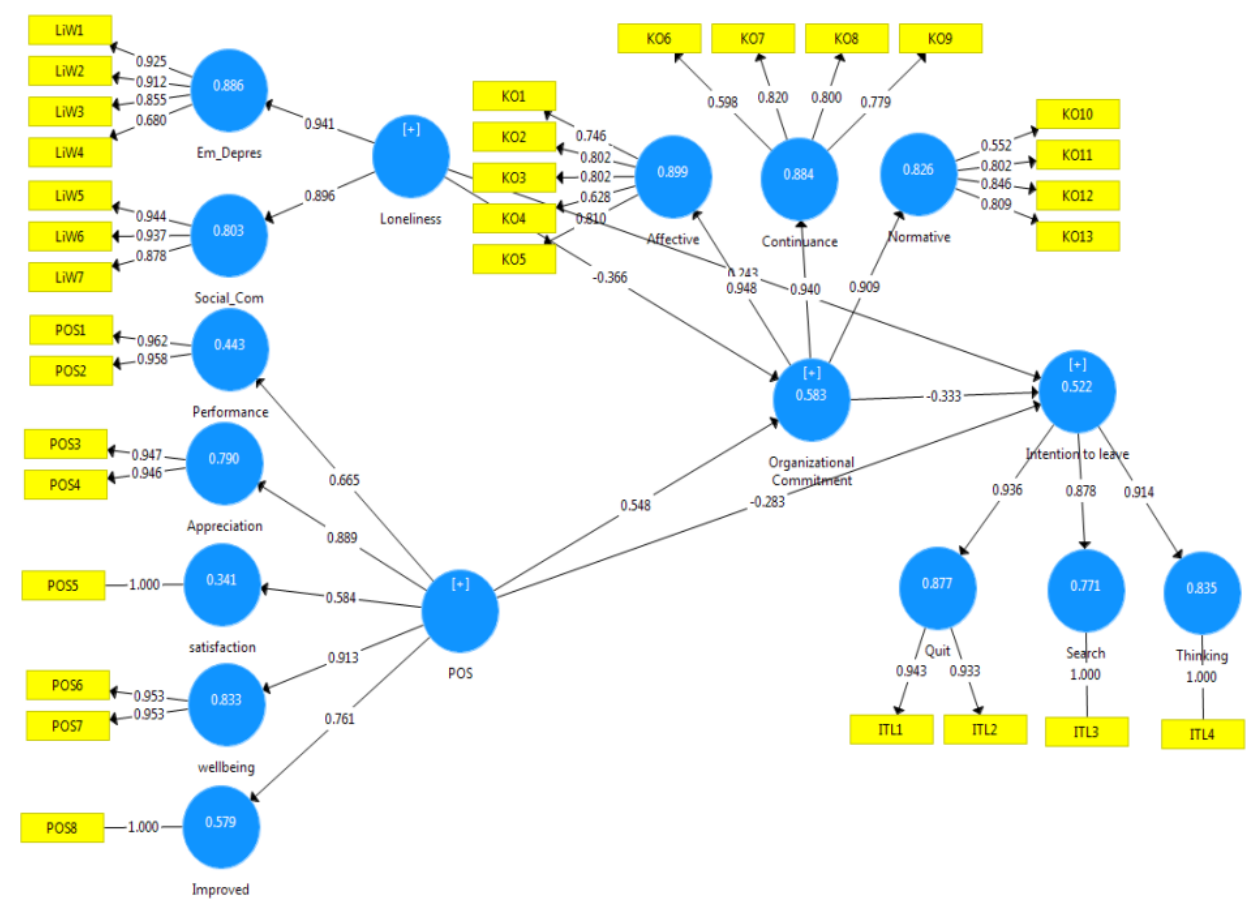

Figure 1: Result Analysis of Convergent Validity; Source: processed primary data, 2021

Table 2: Indicator Test Outer Loadings

\begin{tabular}{|c|c|c|c|c|}
\hline \multirow[t]{2}{*}{ No } & \multirow[t]{2}{*}{ Variable Relation - Indicator } & \multicolumn{3}{|l|}{ Test Result } \\
\hline & & Loading Factor & $\mathrm{P}$ Values & Notes \\
\hline 1 & ITL1<- Quit & 0.943 & 0.000 & Valid \\
\hline 2 & ITL1 <- Intention to leave & 0.909 & 0.000 & Valid \\
\hline 3 & ITL2 <- Quit & 0.933 & 0.000 & Valid \\
\hline 4 & ITL2 <- Intention to leave & 0.846 & 0.000 & Valid \\
\hline 5 & ITL3 <- Search & 1.000 & & Valid \\
\hline 6 & ITL3 <- Intention to leave & 0.878 & 0.000 & Valid \\
\hline 7 & ITL4 <- Thinking & 1.000 & & Valid \\
\hline 8 & ITL4 <- Intention to leave & 0.914 & 0.000 & Valid \\
\hline 9 & KO1 <- Affective & 0.746 & 0.000 & Valid \\
\hline 10 & KO1 <- Organizational Commitment & 0.690 & 0.000 & Valid \\
\hline 11 & KO10 <- Normative & 0.552 & 0.000 & Valid \\
\hline 12 & KO10 <- Organizational Commitment & 0.534 & 0.000 & Valid \\
\hline 13 & KO11 <- Normative & 0.802 & 0.000 & Valid \\
\hline 14 & KO11 <- Organizational Commitment & 0.690 & 0.000 & Valid \\
\hline 15 & KO12<- Normative & 0.846 & 0.000 & Valid \\
\hline 16 & KO12<- Organizational Commitment & 0.795 & 0.000 & Valid \\
\hline 17 & KO13 <- Normative & 0.809 & 0.000 & Valid \\
\hline 18 & KO13 <- Organizational Commitment & 0.720 & 0.000 & Valid \\
\hline 19 & $\mathrm{KO} 2<-$ Affective & 0.802 & 0.000 & Valid \\
\hline 20 & $\mathrm{KO} 2<-$ Organizational Commitment & 0.775 & 0.000 & Valid \\
\hline
\end{tabular}




\begin{tabular}{|c|c|c|c|c|}
\hline & Table Cont'd & & & \\
\hline 21 & KO3 <- Affective & 0.802 & 0.000 & Valid \\
\hline 22 & KO3<- Organizational Commitment & 0.743 & 0.000 & Valid \\
\hline 23 & KO4 <- Affective & 0.628 & 0.000 & Valid \\
\hline 24 & KO4 <- Organizational Commitment & 0.606 & 0.000 & Valid \\
\hline 25 & KO5 <- Affective & 0.810 & 0.000 & Valid \\
\hline 26 & KO5 <- Organizational Commitment & 0.777 & 0.000 & Valid \\
\hline 27 & KO6 <- Continuance & 0.598 & 0.000 & Valid \\
\hline 28 & KO6 <- Organizational Commitment & 0.546 & 0.000 & Valid \\
\hline 29 & KO7 <- Continuance & 0.820 & 0.000 & Valid \\
\hline 30 & KO7 <- Organizational Commitment & 0.855 & 0.000 & Valid \\
\hline 31 & KO8 <- Continuance & 0.800 & 0.000 & Valid \\
\hline 32 & KO8<- Organizational Commitment & 0.711 & 0.000 & Valid \\
\hline 33 & KO9 <- Continuance & 0.779 & 0.000 & Valid \\
\hline 34 & KO9 <- Organizational Commitment & 0.683 & 0.000 & Valid \\
\hline 35 & LiW1<- Em_Depres & 0.925 & 0.000 & Valid \\
\hline 36 & LiW1 <- Loneliness & 0.810 & 0.000 & Valid \\
\hline 37 & LiW2 <- Em_Depres & 0.912 & 0.000 & Valid \\
\hline 38 & LiW2 <- Loneliness & 0.834 & 0.000 & Valid \\
\hline 39 & LiW3 <- Em_Depres & 0.855 & 0.000 & Valid \\
\hline 40 & LiW3 <- Loneliness & 0.744 & 0.000 & Valid \\
\hline 41 & LiW4 <- Em_Depres & 0.680 & 0.000 & Valid \\
\hline 42 & LiW4 <- Loneliness & 0.785 & 0.000 & Valid \\
\hline 43 & LiW5 <- Social_Com & 0.944 & 0.000 & Valid \\
\hline 44 & LiW5 <- Loneliness & 0.888 & 0.000 & Valid \\
\hline 45 & LiW6 <-Social_Com & 0.937 & 0.000 & Valid \\
\hline 46 & LiW6 <- Loneliness & 0.850 & 0.000 & Valid \\
\hline 47 & LiW7 <- Social_Com & 0.878 & 0.000 & Valid \\
\hline 48 & LiW7 <- Loneliness & 0.724 & 0.000 & Valid \\
\hline 49 & POS1 <- Performance & 0.962 & 0.000 & Valid \\
\hline 50 & POS $1<-$ POS & 0.653 & 0.000 & Valid \\
\hline 51 & POS2 <- Performance & 0.958 & 0.000 & Valid \\
\hline 52 & POS $2<-$ POS & 0.624 & 0.000 & Valid \\
\hline 53 & POS3 <- Appreciation & 0.947 & 0.000 & Valid \\
\hline 54 & POS3 <- POS & 0.844 & 0.000 & Valid \\
\hline 55 & POS4 <- Appreciation & 0.946 & 0.000 & Valid \\
\hline 56 & POS4 <- POS & 0.839 & 0.000 & Valid \\
\hline 57 & POS5 <- satisfaction & 1.000 & 0.000 & Valid \\
\hline 58 & POS5 <- POS & 0.584 & 0.000 & Valid \\
\hline 59 & POS6 <- wellbeing & 0.953 & 0.000 & Valid \\
\hline 60 & POS6 <- POS & 0.867 & 0.000 & Valid \\
\hline 61 & POS7 <- wellbeing & 0.953 & 0.000 & Valid \\
\hline 62 & POS7 <- POS & 0.873 & 0.000 & Valid \\
\hline 63 & POS8 <- Improved & 1.000 & 0.000 & Valid \\
\hline 64 & POS $8<-$ POS & 0.761 & 0.000 & Valid \\
\hline
\end{tabular}




\section{Discriminant validity (Cross Loading)}

The model has sufficient discriminant validity if the AVE root for each construct is greater than the correlation between the constructs in the model at the PLS output as can be shown in Table 2. This AVE root value is higher than the coefficient correlation on the Intention to leave variable with other constructs (Loneliness, Organizational Commitment, and POS) which have a coefficient correlation ranging from -0.665 to 0.538 . Thus, the construct of Intention to leave can be declared valid because the root AVE > the coefficient correlation. Likewise, other variables can be seen in the same way, so that it can be stated that all of these variables have high discriminant validity.

Table 3: Discriminant validity

\begin{tabular}{lllll}
\hline & Intention to leave & Loneliness & Organizational Commitment & POS \\
\hline Intention to leave & $0.887^{*}$ & & & \\
\hline Loneliness & 0.538 & $0.807^{*}$ & & \\
\hline Organizational Commitment & -0.665 & -0.570 & $0.708^{*}$ & $0.764^{*}$ \\
\hline POS & -0.601 & -0.371 & 0.684 \\
\hline
\end{tabular}

Note : * value of ROOT AVE

\section{Construct Reliability Test (Composite Reliability)}

From Table 4, it can be seen that the value of all variables in reliability testing using validity testing using AVE with a value of more than 0.5 or Composite Reliability is more than 0.7 . Therefore, it can be concluded that the tested variables are valid and also reliable so that it can be continued to test the structural model. In addition to the construct validity, a construct reliability test was carried out as measured by the composite reliability of the indicator block which measures the construct. The construct is declared reliable if the composite reliability value is above 0.70 (Ghozali, 2015).

Table 4: Composite Reliability

\begin{tabular}{llll}
\hline & Cronbach's Alpha & Composite Reliability & Average Variance Extracted (AVE) \\
\hline Intention to Leave & 0.909 & 0.937 & 0.787 \\
\hline Workplace Loneliness & 0.910 & 0.929 & 0.651 \\
\hline Organizational commitment & 0.915 & 0.928 & 0.501 \\
\hline Organizational support & 0.894 & 0.916 & 0.583 \\
\hline
\end{tabular}

\section{Structural Model Analysis (Inner Model)}

\section{Determination Coefficient (R2)}

The model provides an R-square value of 0.522 on the organizational commitment variable, meaning that the ability of the model for the workplace loneliness variable and Perceived Organizational Support in explaining the organizational commitment variable is $52.2 \%$ and the remaining $47.8 \%$ is explained by other variables. While the R-square value of Intention to Leave is 0.583 , which means that the model's ability on workplace loneliness variable, Perceived Organizational Support variable, and organizational commitment variable in explaining the Intention to Leave is $58.3 \%$ and the remaining $41.7 \%$ is explained by other variables.

Table 5: Result of R-Square Testing

\begin{tabular}{lll}
\hline Independent Variable & Dependent & R Square \\
\hline Perceived Organizational Support & Organizational Commitment & 0,522 \\
\hline Workplace Loneliness & Intention to Leave & 0.583 \\
Perceived Organizational Support & & \\
Organizational Commitment & & \\
\hline
\end{tabular}

\section{Predictive Relevance}

If the Q-square value is $>0$, it indicates that the model has predictive relevance, on the other hand, if the Q-square value is $\leq 0$, it indicates that the model lacks the predictive relevance (Chin, 1998). Based on the results of the determination coefficient above, the Q Square value can be calculated as follows:

$\mathrm{Q}^{2}=1-\{(1-0,522) \times(1-0,583))$

$\mathrm{Q}^{2}=1-0,199$

$\mathrm{Q}^{2}=0,801$ 
The Q2 coefficient of 0.801 shows that the total influence of the workplace loneliness variable and perceived organizational support on the Intention to Leave through organizational commitment is $80.1 \%$. While the remaining $19.9 \%$ is explained by other variables. The value of $\mathrm{Q} 2>0$ indicates that the model has predictive relevance.

\section{Hypothesis Test}

\section{Direct Effects}

Table 6: Result of Direct Effects Testing

\begin{tabular}{|c|c|c|c|c|c|c|}
\hline & $\begin{array}{l}\text { Original } \\
(\mathbf{O})\end{array}$ & Sample & $\begin{array}{l}\text { T } \\
(\mid \text { O/STDEV } \mid)\end{array}$ & Statistics & $\begin{array}{l}\mathbf{P} \\
\text { Values }\end{array}$ & $\begin{array}{l}\text { Descriptio } \\
\text { n }\end{array}$ \\
\hline $\begin{array}{llll}\text { Workplace loneliness } & \rightarrow & \text { Organizational } \\
\text { Commitment } & & & \end{array}$ & -0.366 & & 3.999 & & 0.000 & $\begin{array}{l}\mathrm{H} 1 \\
\text { accepted }\end{array}$ \\
\hline Workplace loneliness -> Intention to leave & 0.243 & & 1.982 & & 0.024 & $\begin{array}{l}\mathrm{H} 2 \\
\text { accepted }\end{array}$ \\
\hline POS -> Organizational Commitment & 0.548 & & 6.656 & & 0.000 & $\begin{array}{l}\mathrm{H} 3 \\
\text { accepted }\end{array}$ \\
\hline POS -> Intention to leave & -0.283 & & 3.066 & & 0.001 & $\begin{array}{l}\mathrm{H} 4 \\
\text { accepted }\end{array}$ \\
\hline Organizational Commitment -> Intention to leave & -0.333 & & 2.672 & & 0.004 & $\begin{array}{l}\text { H5 } \\
\text { accepted }\end{array}$ \\
\hline
\end{tabular}

Note $*=\operatorname{Sig} \mathrm{p}$ values $<0.05$

Indirect Effects

Table 7: Indirect Effects

\begin{tabular}{|c|c|c|c|c|}
\hline \multirow[t]{2}{*}{ Variable Relationship Pattern } & \multicolumn{4}{|c|}{ Indirect Effects } \\
\hline & Coefficient & $\begin{array}{l}\mathrm{T} \\
\text { amount }\end{array}$ & $\begin{array}{l}\mathrm{P} \\
\text { Values }\end{array}$ & Annotation \\
\hline Workplace loneliness -> Organizational commitment-> Intention to Leave & 0.122 & 1.999 & 0.022 & H6 diterima \\
\hline $\begin{array}{l}\text { Perceived organizational support -> Organizational commitment-> Intention } \\
\text { to Leave }\end{array}$ & -0.182 & 2.753 & 0.003 & H7 diterima \\
\hline
\end{tabular}

Note $*=$ Sig $\mathrm{p}$ values $<0.05$

\section{Discussion}

\section{Workplace Loneliness on Organizational Commitment}

The results show that workplace loneliness has a negative and significant effect on employee organizational commitment. The effect of workplace loneliness (X1) on organizational commitment (Z) is obtained with an estimated coefficient value of -0.366 and $t$ count of 3.999 and a probability of $0.000<0.05$, it can be concluded that there is a significant negative effect between workplace loneliness (X1) with organizational commitment (Z), which means H1 is accepted. The existence of a negative influence shows that the high perception of workplace loneliness will reduce organizational commitment, and conversely, the lower the perception of workplace loneliness, the higher the organizational commitment is.

Workplace loneliness manifests itself as sadness due to a lack of quality interpersonal communication between employees in the work environment (Wright, 2005). In perspective, loneliness is defined as a complex emotional reflection due to the failure to establish a relationship by meeting the closest people and to meet one' social needs (Ernst \& Cacioppo, 1999), some unpleasant experiences due to the lack of individual social relationships (Shaver and Brennan, 1991) or some subjective experiences that are influenced by situational variables and personality traits (Rokach \& Neto, 2005). The results of this study are consistent with study conducted by Ayazlar and Güzel (2013) and study conducted by Tabancalı \& Korumaz (2017). This study shows that workplace loneliness strongly predicts their commitment to the organization. Özçelik \& Barsade (2011) states that employees' workplace loneliness triggers their emotional distance from a settlement as a reflection of a decrease in organizational commitment, thus affecting their performance.

\section{Workplace Loneliness on Intention to Leave}

Between workplace loneliness (X1) and the Intention to Leave (Y), the estimated coefficient value is 0.243 and $t$ is 1.982 , and the probability is $0.024<0.05$. Thus it can be concluded that there is a significant positive effect between workplace loneliness (X1) with the Intention to Leave (Y), which means that $\mathrm{H} 2$ is accepted. There is a positive effect of workplace loneliness on Intention to Leave, indicating that the greater the feeling of workplace loneliness is, the higher the Intention to Leave will be. In this context, failure to meet emotional expectations and inadequate social dialog in the workplace will lead individuals to experience feelings of loneliness 
which may result in the individual's intention to leave. Lam \& Lau (2012) explain that employees who have social relationships and trust that are less likely to be prioritized and appear for the organization. This makes them feel that their goals are not in line with the goals of the organization, thus encouraging them to seek alternative assistance from other organizations.

Thus, it is concluded that loneliness can have a negative impact on organizational commitment, which in turn, may affect the intention to leave (Ertosun \& Erdil, 2012). This is in line with study conducted by Aytac and Basol (2018). The results of this study indicate that there is a positive and significant influence between loneliness and Intention to Leave. The results are consistent with studies conducted by Kaymaz et al., (2014), Ghadi (2017), and Gozukara et al., (2017) which state that workplace loneliness has a positive and significant impact on employees Intention to Leave.

\section{Perceived Organizational Support on Organizational Commitment}

The influence of Perceived Organizational Support (X2) with Organizational Commitment (Z) is obtained with an estimated coefficient value of $0.548, \mathrm{t}$ count is 6.656 and a probability of 0.000 where the value is less than 0.05 (significance level of $5 \%$ ), it can be concluded that there is a significant positive influence between Perceived organizational support (X2) and Organizational Commitment $(\mathrm{Z})$. The positive coefficient shows that the better the perceived organizational support provided to employees is, the higher the organizational commitment they have and vice versa. Study by Eisenberger et al., (1990) states that employees who receive support from their organization are less likely to look for other jobs or will not accept job offers from other companies. Organizational support is seen as a very important factor in the behavior of its employees, this support can be in the form of attention from the leadership to their subordinates. It can also be in the form of adequate facilities and infrastructure to support its employee's performance, and this strengthens the employee's organizational commitment. In this study there is a positive and significant influence on perceived organizational support on organizational commitment, indicating that the better the perceived organizational support is, the higher and the organizational commitment will be. The results of the study are in line with study by Battistelli et al., (2015) which found that POS has a positive effect on self-competence through affective commitment. Conversely, ongoing commitment and normative commitment do not mediate this relationship. Wong and Wong, (2017) also show that POS has a positive effect on organizational commitment. In addition, Islam et al., (2015) and Brown and Roloff (2015) show that perceived organizational support has a positive effect on organizational commitment. POS is believed to increase employee affective commitment.

\section{Perceived Organizational Support towards Intention to Leave}

The results of the study indicate that perceived organizational support on the Intention to Leave has an estimated coefficient value of -0.283 , with a t count of 3.066 and a probability of 0.001 where the value is less than 0.05 (significance level of $5 \%$ ), it can be concluded that there is a significant negative influence between perceived organizational support (X2) and the Intention to Leave (Y) means that $\mathrm{H} 4$ is accepted. Increased perceived organizational support can make employees feel obliged to contribute and care about the welfare of the organization and help the organization to achieve its goals (Eisenberger et al., 2001). Organizational support is defined as employees' general beliefs about the extent to which the organization values their contributions and cares about their wellbeing (Eisenberger et al., 1986). Increased perceived organizational support can make employees feel obliged to contribute and care about the welfare of the organization and help the organization to achieve its goals (Eisenberger et al., 2001).

Positive work experience can create employees with a good level of perceived organizational support (Gupta et al., 2010). Not all organizations could and are able to provide full support to employees, therefore some solutions have emerged, one of which is an increase in work ability which can minimize the incidence of low POS from employees, which has an impact on employees' desire to leave (Yahya et al., 2012). The results of the study support the studies conducted by Madden et al., (2015) and Barzoki and Rezai (2017) showing the same results that POS has a negative effect on Intention to Leave. Meanwhile, Ghozali et al., (2018) and Guchait et al., (2015) show that POS has a negative and significant effect on the desire to leave the organization. This shows that with the increase in POS, employees will have lower intention to leave so that the intention will increase along with the increase of POS.

\section{Organizational Commitment on Intention to Leave}

The results of the study indicate that the estimated coefficient value of $-0.333, \mathrm{t}$ count of 2.672 , and a probability of 0.004 where the value is less than 0.05 (5\% significance level). It can be concluded that there is a significant negative effect between organizational commitment $(\mathrm{Z})$ with the Intention to Leave (Y), which means that H5 is accepted. Organizational commitment to the company prevents unwanted Intention to Leave (Handaru, 2012). This means that the greater the organizational commitment possessed by employees is, the lower the turnover intensity of employees will be. High organizational commitment tends to reduce the desire of employees to leave the company. In which employees who have high organizational commitment will have low intention to leave. With the increase of job satisfaction and organizational commitment, it is expected that the employee's intention or goal to leave the organization will decrease. Results from studies conducted by Rawashdeh and Tamimi (2019) and Omar (2012) show that organizational commitment has a negative effect on Intention to Leave. Meanwhile, results from a study by Islam et al., (2015) show that there is a negative and significant relationship between Affective Commitment in relation to Intention to Leave felt by employees in the banking sector. 


\section{Workplace Loneliness on Intention to Leave is mediated by Organizational Commitment.}

Furthermore, workplace loneliness has a positive and significant effect on the Intention to Leave which is mediated by the organizational commitment variable on the employees. Based on the Indirect Effect Test, it is known that the coefficient of the indirect effect of workplace loneliness $(\mathrm{X} 1)$ on the Intention to Leave $(\mathrm{Y})$ through organizational commitment $(\mathrm{Z})$ is 0.122 with a significance test obtained by the $t$ value of 1.999 and a probability of 0.022 where this value smaller than 0.05 (at a significant level of 5\%). It can be concluded that there is a significant influence between workplace loneliness (X1) on the Intention to Leave (Y) through organizational commitment (Z) meaning that H6 is accepted. According to Ertosun \& Erdil (2012), employees who have workplace loneliness due to employees' dissatisfaction will tend to withdrawal from their organization, either through psychological termination or actual job termination. In addition, poor relationships with coworkers emerged as the most prominent reason for withdrawing from the organization after their poor organizational commitment. Thus workplace loneliness has a negative effect on employees' attitudes which will reduce organizational commitment and increase the desire to withdraw from the organization. The results of the study support the studies of Wright (2005) and Ertosun \& Erdil (2012) by using quantitative analysis which aims to investigate the effect of Organizational Commitment as a mediating variable in relation to Loneliness and Intention to Leave. From the results of study conducted by Kaymaz et al., (2014), it is suggested that loneliness can cause stress, weak organizational commitment, and problems in social relationships, which in turn can trigger a desire to leave the organization.

\section{Perceived Organizational Support on Intention to Leave is mediated by Organizational Commitment}

Based on the test, it can be seen that the coefficient of indirect influence on perceived organizational support (X2) on the Intention to Leave $(\mathrm{Y})$ through organizational commitment $(\mathrm{Z})$ is -0.182 with a significance test obtained by the $\mathrm{t}$ value of 2.753 and probability of 0.003 , where the value is smaller than 0.05 (at a significant level of 5\%). It can be concluded that there is a significant influence between perceived organizational support (X2) on the Intention to Leave (Y) through organizational commitment (Z), which means that $\mathrm{H7}$ is accepted. Perceived organizational support has a negative and significant effect on the Intention to Leave mediated by the organizational commitment variable. The results of the study support the study of Maertz et al., (2007) which found that affective and normative commitment can mediate the relationship between POS and Intention to Leave. A person who has great organizational support and has a strong drive to increase his organizational commitment can lead to a positive mood at work which can lead to positive emotional associations with the organization itself, thereby increasing affective commitment and reducing turnover rates. The results of Wong and Wong's (2017) and Zhang's (2019) studies show that affective commitment mediates the relationship between POS and employee Intention to Leave. Affective commitment has a negative and significant effect on Intention to Leave and POS has a significant positive effect on affective commitment. The results from studies by Albalawi et al., (2019) and Waddell (2016) show that organizational commitment is a mediator between POS and Intention to Leave and their relationship becomes weak when employee job satisfaction is high. Job satisfaction has been shown to increase organizational commitment and reduces the desire to leave. So, it can be concluded that POS can increase organizational commitment.

\section{Conclusions}

This research aims to examine and analyze the impact of workplace loneliness and perceived organizational support towards Intention to Leave that is mediated by organizational commitment, surveyed among employees of securities company that are parts of Indonesian Stock Exchange (BEI). The research result shows that workplace loneliness and perceived organizational support has a significant impact towards Intention to Leave. This means that the higher perceived workplace loneliness is, the lower the organizational commitment is. In addition, the higher the perceived workplace loneliness is, the higher the Intention to Leave is and vice versa.

Furthermore, there is a negative correlation between organizational commitment towards Intention to Leave. If the organizational commitment gets better, the perceived organizational commitment among employees increases along with it, thus leads to a decrease in Intention to Leave and vice versa. Therefore, this research reveals that organizational commitment is proven to mediate the notion between workplace loneliness and Intention to Leave. This means that if the workplace loneliness increases, then the organizational commitment decreases, resulting in the increase of Intention to Leave among employees. Organizational commitment also mediates the relation between perceived organizational support towards Intention to Leave. This means that if the perceived organizational support gets better, then the organizational commitment most likely increases too, and this can suppress the Intention to Leave among employees.

Having this considered, companies need to ensure that the rate of workplace loneliness can be suppressed, especially on the dimension of emotional depression which is often ignored among workmates in an under-pressure situation. Employees tend to feel extremely pressured when they are ignored by their peers and chief officer in their office. The increase of perceived organizational support variable, especially on the dimension of improved performance dimension, is deemed as the lowest by the employee. An approach to lower level through coaching is also perceived as an appropriate attempt for lower-level employee to obtain proper acknowledge regarding the concept of job that needs to be finished. Another thing that can be done includes personal discussion and this can further emphasize a good organizational support. In order to increase organizational commitment, an open communication among employees can get them to feel seen, acknowledged, and appreciated as parts of the team as well as the company. 
The researcher is fully aware that the result of this research still has limitations, one of them being the pandemic of COVID 19 that only enables the researcher to carry out the questionnaire survey online, thus limits the control and assistance towards respondents. Aside from the lack of previous research with similar topic as this research, the distribution of questionnaire also occurred during the rush period of work, so the number of respondents that were willing to participate in the survey was not so big.

\section{References}

Akgunduz, Y., \& Sanli, S.C. (2017). The Effect Of Employee Advocacy and Perceived Organizational Support on Job Embeddedness and Intention to Leave in Hotels. Journal of Hospitality and Tourism Management, 31(2017), 118-125.

Albalawi, A.S., Naugton, S., Elayan, M. B., \& Sleimi, M. T. (2019). Perceived Organizational Support, Alternative Job Opportunity, Organizational Commitment, Job Satisfaction and Intention to Leave: A Moderated-mediated Model. Organizacija, 52(4), 310-324.

Allen, D.G., Shore, L. M., \& Griffeth, R. W. (2003). Role Of Perceived Organizational Support and Supportive Human Resource Practices in The Turnover Process. Journal of Management, 29(1), 99-118.

Ayazlar, G., \& Güzel, B. (2014). The Effect of Loneliness in the Workplace on Organizational Commitment. Procedia - Social and Behavioral Sciences, 131, 319-325.

Aytac, S. (2015). Loneliness as Mediator between Job Satisfaction and Intention to Leave: A Study on Prison Staff in Turkey. Arabian Journal of Business and Management Review, 5(6), 1-4.

Aytac, S., \& Basol, O. (2018). Mediating Role of Loneliness and Organizational Conflict Between Work Overload and Intention to Leave. Proceedings of the 20th Congress of the International Ergonomics Association (IEA 2018), 291-301.

Barzoki A.S., \& Rezaei, A. (2017). Relationship Between Perceived Organisational Support, Organisational Citizenship Behaviour, Organisational Trust and Intention to Leaves: an Empirical Case Study. International. Journal Productivity and Quality Management, 21(3), 273-298.

Battistelli, A., Galletta, M., Vandenberghe, C., \& Odoardi, C. (2015). Perceived Organisational Support, Organisational Commitment And Self-Competence Among Nurses: A Study In Two Italian Hospitals. Journal of Nursing Management, 24(1), 1- 10.

Bhatti, M.H., Bhatti, H.M., Akram1, U. \& Bilal, M. (2016), "Impact of Organization Commitment on Intention to Leave: Mediating Role of Job Contentment", European Journal of Business and Management, 8(13), 24-39.

Boswell, W. R., Watkins, M. B., Triana, M. del C., Zardkoohi, A., Ren, R., \& Umphress, E. E. (2012). Second-Class Citizen? Contract Workers' Perceived Status, Dual Commitment and Intent to Quit. Journal of Vocational Behavior, 80(2), 454-463.

Brown, B. (2003).“Employees' Organizational Commitment and Their Perception of Supervisors' Relations Oriented and TaskOriented Leadership Behaviors", Ph.D. Thesis, Virginia Polytechnic Institute and State University.

Brown, L. A., \& Roloff, M. E. (2015). Perceived Organizational Support. The International Encyclopedia of Interpersonal Communication, 1, 1-10.

Cacioppo, J.T. \& Patrick, W. (2008). Loneliness: Human Nature and The Need for Social Conntection. New York, NY: W.W.Norton \& Company.

Chan, S.H., \& Qiu, H.H. (2011). Loneliness, Job Satisfaction, and Organizational Commitment of Migrant Workers: Empirical Evidence From China. The International Journal of Human Resource Management, 22(5), 1109-1127.

Chen, Y., Wen, Z., Peng, J., \& Liu, X. (2016). Leader-Follower Congruence in Loneliness, LMX and Intention to Leave. Journal of Managerial Psychology, 31(4), 864-879.

Cook, J.D., Hepworth, S. J., Wall, T.D., Warr, P. B., (1981). 'The Experience of Work A Compendium and Review of 249 Measures and Their Use'. Academic Pres, 68-69.

Deniz, S. (2019). Effect Of Loneliness In The Workplace On Employees' Job Performance: A Study For Hospital Employees. International Journal of Health Services Research and Policy. 4(3), 214-224.

Dinç, E. (2015). Perceived Organizational Support as a Mediator of the Relationship between Effort-Reward Fairness, Affective Commitment, and Intention to Leave. International Business Research, 8(4), 259-269.

Eisenberger, R., \& Stinglhamber, F. (2011). Perceived Organizational Support: Fostering Enthusiastic and Productive Employees. Washington, DC: American Psychological Association.

Eisenberger, R., Huntington, R., Hutchison, S., \& Sowa, D. (1986). Perceived Organizational Support. Journal of Applied Psychology, 71(3), 500-507.

Eisenberger, R., Malone, G.P., \& Presson, W. D. (2016). Optimizing Perceived Organizational Support to Enhance Employee Engagement. SHRM-SIOP Science of HR series, 1-22.

Ellingwood, S. (2001). The Collective Advantage, Contrary to Popular Belief, Workplace Friendships Boost Profit. Gallup Management Journal.

Ernst, J.M. \& Cacioppo, J.T. (1999). Lonely Hearts: Psychological Perspectives on Loneliness. Applied \& Preventive Psychology, $8(1), 1-22$.

Ertosun, Ö.G., \& Erdil, O. (2012). The Effects of Loneliness on Employees' Commitment and Intention to Leave. Procedia - Social and Behavioral Sciences, 41, 469-476.

Ford, T.G., Olsen, J., Khojasteh, J., Ware, J., \& Urick, A. (2019), "The Effects Of Leader Support For Teacher Psychological Needs On Teacher Burnout, Commitment, And Intent To Leave", Journal of Educational Administration, 57(6), 615-634. 
Garg, N., \& Anand, P. (2020). Knowledge Hiding, Conscientiousness, Loneliness and Affective Commitment: A Moderated Mediation Model. International Journal of Educational Management, 34(9), 1-21.

Ghadi, M.Y. (2017), "The Impact of Workplace Spirituality on Voluntary Intention to Leaves Through Loneliness in Work". Journal of Economic and Administrative Sciences, 33(1), 81-110.

Ghazali, H., Nashuki, N.M., \& Othman, M. (2018). The Influence of Perceived Organizational Support (POS), Perceived Supervisory Support (PSS) and Organizational Commitment (OC) towards Intention to Leave or Intention to Stay: A case of Casual Dining Restaurants in Klang Valley, Malaysia. International Journal of Academic Research in Business and Social Sciences, 8(9), 1884-1902.

Ghozali, I. (2014). Partial Least Squares, Konsep, Metode dan Aplikasi Menggunakan Program WarpPLS 4.0, Semarang, Badan Penerbit - Undip.

Ghozali, I., \& Latan, H. (2015). Partial Least Square Konsep Teknik dan Aplikasi Menggunakan Program SmartPLS 3.0 (2nd Edition). Semarang: Badan Penerbit Universitas Diponegoro.

Ghozali, Imam. (2018). Aplikasi Analisis Multivariate Dengan Program SPSS. Cetakan Kesembilan. Semarang: Badan Penerbit Universitas Diponegoro.

Gozukara, I., Mercanlı, A., Çapuk, S \& Yıldırım, O. (2017). Impact of Intention to Leave on Loneliness and the Mediating Effect of Work Alienation. Business Management and Strategy, 8 (1), 18-38.

Guchait, P., Cho, S., \& Meurs, J. A. (2015). Psychological Contracts, Perceived Organizational and Supervisor Support: Investigating the Impact on Intent to Leave Among Hospitality Employees in India. Journal of Human Resources in Hospitality \& Tourism, 14(3), 290-315.

Haryono, S. (2016). Metode SEM Untuk Penelitian Manajemen dengan AMOS 22.00, LISREL 8.80 dan Smart PLS 3.0. Jakarta : Badan Penerbit PT. Intermedia Personalia Utama.

Hawkley, L.C., \& Cacioppo, J.T. (2010), "Loneliness Matters: A Theoretical And Empirical Review Of Consequences And Mechanisms", Annals of Behavioral Medicine, 40(2), 218-227.

Hashish, E.A.A. (2015). Relationship Between Ethical Work Climate and Nurses' Perception of Organizational Support, Commitment, Job Satisfaction and Turnover Intent. Nursing Ethics, 24(2), 151-166.

Hom, P.W., \& Griffeth, R.W. (1991). Structural Equations Modeling Test of A Turnover Theory: Cross-Sectional and Longitudinal Analyses. Journal of Applied Psychology, 76(3), 350-366.

Irfanto, R., \& Pandowo, M. (2015). The Effect of Perceived Organizational Support and Job Satisfaction Toward Intention to Leave of Plaza Bangunan \& Electronic Calaca, Manado. Jurnal Riset Ekonomi, Manajemen, Bisnis Dan Akuntansi , 3(3), $788-797$.

Islam,T., Ahmed,I. \& Ahmad,U.N.B.U. (2015), "The Influence of Organizational Learning Culture and Perceived Organizational Support on Employees' Affective Commitment and Intention to Leave", Nankai Business Review International, 6(4),417431.

James, R., \& Azungah, T. (2019), "Repatriation of Academics: Organizational Support, Adjustment and Intention To Leave", Management Research Review, 43(2), 150-165.

Jehanzeb, K., Rasheed, A. \& Rasheed, M. (2013), Organizational Commitment and Intention to Leaves: Impact of Employee's Training in Private Sector of Saudi Arabia, International Journal of Business and Management, 8(8), 79-90.

Jung, H.S., Song, M.K., Yoon, H.H. (2021) The Effects of Workplace Loneliness on Work Engagement and Organizational Commitment: Moderating Roles of Leader-Member Exchange and Coworker Exchange. Sustainability. 3(2). 948.

Jawahar, M., \& Hemmasi, P. (2006),"Perceived Organizational Support For Women's Advancement AndIntention to Leaves", Women in Management Review, 21(8), 643 - 661

Kalidass, A., \& Bahron, A. (2015). The Relationship between Perceived Supervisor Support, Perceived Organizational Support, Organizational Commitment and Employee Intention to Leave. International Journal of Business Administration, 6(5), 8289.

Kaymaz, K., Eroğlu, U., \& Sayılar Y. (2014). Effect of Loneliness at Work on The Employees' Intention to Leave. Industrial Relations and Human Resources Journal, 16(1), 38-53.

Kim, D., Wolf-Wendel, L., \& Twombly, S. B. (2013). The role of citizenship status in intent to leave for pre-tenure faculty. Journal of Diversity in Higher Education, 6(4), 245-260.

Kim, K.Y., Eisenberger, R., \& Baik, K. (2016). Perceived organizational support and affective organizational commitment: Moderating influence of perceived organizational competence. Journal of Organizational Behavior, 37(4), 558-583.

Kraus, L.A., Davis, M.H., Bazzini, D., Church, M. \& Kirchman, C.M. (1993). Personal and Social Influences on Loneliness: The Mediating Effect of Social Provisions. Social Psychology Quarterly, 56(1), 37-53.

Lam, L.W., \& Lau, D.C. (2012). Feeling Lonely at Work: Investigating The Consequences of Unsatisfactory Workplace Relationships. The International Journal of Human Resource Management, 23(20), 4265-4282.

Lee, O.C., Yusof, A., Geok. S.K., \& Omar, Z. (2017). Examine The Relationship Between Organisational Justice And Organizational Commitment With Perceived Organisational Support of The Malaysian High Performance School Sports Developmental Programme (SPTS) Volunteer Coaches. International Journal of Academic Research in Business and Social Sciences, 7(4), 588-613.

Lee, T.L., Chen, S.Y., Wang, S.H., \& Dadura, A. (2010), “The Relationship Between Spiritual Management And Determinants Of Intention to Leave”, European Business Review, 22(1), 102-116. 
Loi, R., Hang-Yue, N., \& Foley, S. (2006). Linking Employees' Justice Perceptions To Organizational Commitment and Intention to Leave: The Mediating Role Of Perceived Organizational Support. Journal Of Occupational And Organizational Psychology, 79(1), 101-120.

Madden, L., Mathias, B.D., \& Madden, T.M. (2015). In Good Company : The Impact of Perceived Organizational Support and Positive Relationships at Work on Intention to Leaves. Management Research Review, 38(3), 242-263.

Maertz Jr, C., Griffeth, R.W., Campbell, N.S., \& Allen, D.G. (2007). The Effects of Perceived Organizational Support and Perceived Supervisor Support on Employee Turnover. Journal of Organizational Behavior, 28(8), 1059-1075.

Matier, M.W. (1990). Retaining faculty: A tale of two campuses. Research in Higher Education, 31(1), 39-60.

Meyer J.P. \& Allen N.J. (1990). The Measurement and Antecedents of Affective, Continuance, and Normative Commitment to Organization. Journal of occupational psychology, 63(1), 1-18.

Meyer J.P. \& Allen N.J. (1991) A Three-Component Conceptualization of Organizational Commitment. Human Resource Management Review, 1(1), 61-89.

Meyer, J.P., Stanley, D.J., Herscovitch, L. \& Topolnytsky, L. (2002), “Affective, Continuance, and Normative Commitment to The Organization: A Meta-Analysis of Antecedents, Correlates, and Consequences”, Journal of Vocational Behavior, 61(1), 2052.

Mobley, W.H. (1982). Employee Turnover: Causes, Consequences and Control, MA, Addison-Wesley.

Mobley, W.H., Hollingsworth, A.T. \& Horner,S.A. (1978). An Evaluation Of Precursors Of Hospital Employee Turnover. Journal of Applied Psychology, 63(4), 408-414.

Morrison, R. (2004). Informal Relationships in the Workplace: Associations with Job Satisfaction, Organizational Commitment and Intention to Leaves. New Zealand Journal of Psychology, 33(3), 114-128.

Mowday, R., Porter, L. and Steers, R. (1982) Employee-Organization Linkages: The Psychology of Commitment, Absenteeism, and Turnover. Academic Press, New York.

Nagar, K. (2012). "Organizational Commitment and Job Satisfaction Among Teachers During Times Of Burnout", Vikalpa: The Journal for Decision Makers, 37(2), 43-60.

Nazir, O., \& Islam, J.U. (2017), Enhancing Organizational Commitment and Employee Performance Through Employee Engagement (An empirical check). South Asian Journal of Business Studies. 6(1), 98-114.

Omar, K., Anuar,M.M., Majid, A.H.A., \& Johari, H. (2012). Organizational Commitment and Intention To Leave Among Nurses: The Mediating Role Of Moral Obligation. IJMS 19(2), 31-46.

Othman, S.Z., \& Shkuri, N. S.M. (2015). Predicting Intention to Leave Through Organizational Support and Organizational Commitment: The Case Of A Manufacturing Company. International Journal Of Management Studies, 2(1), 33-45.

Ozcelik, H., \& Barsade, S. (2011). Work Loneliness And Employee Performanc. Academy Of Management Academy of management proceedings. 2011 (1), 1-6.

Ozcelik, H., \& Barsade, S. (2018). No Employee An Island: Workplace Loneliness and Job Performance. Academy Of Management Journal. 61(6), 2343-2366.

Park, J.H., Newman, A., Zhang, L., Wu, C., \& Hooke, A. (2015). Mentoring Functions and Intention to Leave: The Mediating Role of Perceived Organizational Support. The International Journal of Human Resource Management, 27(11), 1173-1191.

Peplau, A., \& Perlman, D. (1982). Loneliness : A Sourcebook Of Current Theory, Research, and Therapy. New York : Wiley Interscience.

Perlman, D., \& Joshi, P. (1989). The revelation of loneliness. In M. Hojat \& R. Crandall (Eds.), Loneliness: Theory, Research and Application: 63-76. Newbury Park, CA: Sage Publications.

Perryer, C., Jordan, C., Firns, I., \& Travaglione, A. (2010). Predicting Intention to Leaves. Management Research Review, 33(9), 911-923.

Porter, L.W., Steers, R.M., Mowday, R.T. \& Boulian, P.V. (1974), “Organizational Commitment, Job Satisfaction, and Turnover Among Psychiatric Technicians", Journal of Applied Psychology, 59(5), 603-609.

Promsri, C. (2018). The Influence of Employees' Organizational Commitment on Workplace Loneliness. Social Science and Humanities Journal, 8(2), 432-437.

Rawashdeh, A.M. \& Tamimi, S.A. (2019). The Impact Of Employee Perceptions of Training On Organizational Commitment and Intention to Leave: An Empirical Study of Nurses in Jordanian Hospitals. European Journal of Training and Development, 44(2/3), 191-207.

Rhoades, L \& Eisenberger, R. (2002). Perceived Organizational Support: A Review of the Literature. Journal of Applied Psychology. $87(4), 698-714$.

Sekaran, U. \& Bougie, R. (2013). Research Methods for Business: A Skill- Building Approach. New York: John Wiley \& Sons, 6th Edition.

Sekaran, U. (2007). Research Methods for Business: Methodologi Penelitian untuk Bisnis. Salemba Empat.

Simon, M., Müller, B.H. \& Hasselborn, H.M. (2009). Leaving the Organization or the Profession-a Multilevel Analysis of Nurses' Intentions. Journal of Advanced Nursing. 66(3), 616-626.

Steers, R. M., \& Mowday, R. T. (1981). Employee Turnover and Post-Decision Justification. In L. L. Cummings \& B. M. Staw (Eds.), Research in organizational behavior, 3, 235-282. Greenwich, CT: JAI Press.

Sugiyono. (2014). Metode Penelitian Kuantitatif, Kualitatif, dan Kombinasi (Mixed Methods). Bandung : Alfabeta, CV. 
Sugiyono. (2017). Metode Penelitian Kuantitatif, Kualitatif, dan R\&D. Bandung : Alfabeta, CV.

Tabancal1, E \& Korumaz, M. (2017). Relationship between Supervisors' Loneliness at Work and Their Organizational Commitment. International Online Journal of Educational Sciences, 7(1), 172-189.

Tornstam, L. (1992). Loneliness in Marriage. Journal of Social and Personal Relationships, 9, 197-217.

Tuzun, I.K., \& Kalemci, R.A. (2012), "Organizational And Supervisory Support In Relation To Employee Intention to Leaves", Journal of Managerial Psychology, 27(5), 518-534.

Waddell, K. (2016). "Examining The Relationship Between Procedural Justice, Perceived Organizational Support, Organizational Trust, Organizational Commitment, and Intent To Leave Among Temporary Employees”. Human Resource Development Theses and Dissertations.

Wong, Y.W., \& Wong, Y.W (2017). The Effects of Perceived Organisational Support and Affective Commitment on Intention to Leave. Journal of Chinese Human Resources Management, 8(1), 2-21.

Worku, S.A. (2015). Investigating The Relationship Among Employees Perceived Organizational Support, Perceived Supervisors Support, Job Satisfaction And Intention to Leave. Journal Of Marketing And Consumer Research, 13(2), 1- 8.

Wright, S. L., Burt, C. D. B. \& Strongman, K. T. (2006). Loneliness in the Workplace: Construct Definition and Scale Development. New Zealand Journal of Psychology, 35(2), 59-68.

Wright, S.L. (2005). Loneliness in the Workplace. Doctor of Philosophy in Psychology. University of Canterbury.

Yilmaz, E. (2008). Organizational Commitment And Loneliness And Life Satisfaction Levels Of School Principals. Social Behavior and Personality: An International Journal, 36(8), 1085-1096.

Yilmaz, E., \& Ceylin, S.C. (2017). The Effect Of Employee Advocacy And Perceived Organizational Support On Job Embeddedness And Intention to Leave In Hotels. Journal of Hospitality and Tourism Management, 31(2017), 118-125.

Yoshimura, K.E. (2003). Employee Traits, Perceived Organizational Support, Supervisory Communication, Affective Commitment, And Intent To Leave: Group Differences. Theses Of Psychology.

Yurchisin, J., Park, J., \& O’Brien, M. (2010). Effects Of Ideal Image Congruence and Organizational Commitment on Employee Intention To Leave. Journal of Retailing and Consumer Services, 17(5), 406-414.

Zhang, C. (2012). An Empirical Study Of Effect Of POS Of Knowledge Employees On Intention to Leave. Periodical of SMEs management and technology, 2012(6), 41-42.

Zhang, T. (2019). The Relationship of Perceived Organizational Support to Affective Commitment, Emotional Exhaustion and Intention to Leave - A Study of General Practitioners in Shanghai Community Health Centers in China. Disertation of Doctor of Management. ISCTE University Institute of Lisbon.

Publisher's Note: SSBFNET stays neutral with regard to jurisdictional claims in published maps and institutional affiliations.

\section{(a) (1)}

(c) 2021 by the authors. Licensee SSBFNET, Istanbul, Turkey. This article is an open access article distributed under the terms and conditions of the Creative Commons Attribution (CC BY) license (http://creativecommons.org/licenses/by/4.0/).

International Journal of Research in Business and Social Science (2147-4478) by SSBFNET is licensed under a Creative Commons Attribution 4.0 International License. 